\title{
Re-appreciating the significance of historical perspectives and practices on reformed pastoral theology and care today
}

\author{
Stéphan van der Watt \\ University of the Free State, Bloemfontein, South Africa \\ jsvdwatt@gmail.com
}

\begin{abstract}
This article investigates the issue of Reformed pastoral theology and care, from a historical perspective. Contemporary literature on this topic is not always informed by the actual pastoral care practices of historical church leaders, specifically up until and including the Reformation era. Consequently it can sometimes lack an important dimension needed to foster more theological depth and clarity, which is essential for sound pastoral care. Thus, it is necessary to clearly establish the connections between Reformed theology and practice in historical view, and pastoral care ministries in the church today. Despite huge societal changes that have taken place since the Reformation era, the core focus on the compassionate "care of souls" has remained unchanged. Can leading Reformers' pastoral theological ethos and practices still be deemed relevant, whilst considering fresh issues in our contemporary pastoral care ministry contexts?
\end{abstract}

Key words

Pastoral Theology; Reformation; Soul Care; John Calvin; Martin Bucer

\section{Introduction}

In order to grasp afresh what Reformed pastoral theology and care is supposed to entail today, we need to re-read the history of its development. In light of the recent $500^{\text {th }}$ anniversary of the Reformation (2017), the need to reconsider the historical development of the field of pastoral theology and care - from a Reformed perspective - becomes especially relevant. This article aims to glean fresh insights from the practice of pastoral theology and care - also known as the tradition of cura animarum - as it 
was understood and done up until (and including) the Reformation era. ${ }^{1} \mathrm{~A}$ particular focus on some notable Reformers' pastoral theological ethos and pathos will therefore inform and direct this article. ${ }^{2}$

Pastoral theology, as an academic subfield within practical theology, is closely related to pastoral care, which is an integral part of practical church ministries. ${ }^{3}$ In the Western hemisphere it has been greatly influenced by the American pastoral care and counselling movement, which especially flourished in the years 1940-1970. Much has been gained by clinical pastoral training (CPE), supervisory programmes and counselling skills. Consequently, pastoral care has often acquired a professionalized and functionalist character, dominated by the paradigm of North America and Western Europe. ${ }^{4}$ Andrew Purves (in McKim and Wright 1992:271) however highlights that, "Much has been learned, but at the cost of a lost identity. Contemporary pastoral theology within the Reformed churches is not exempt from this condition."

1 This cura animarum ("cure-of-souls") tradition will be explicated later in this article.

2 Basically the research methodology behind this article consisted of a detailed literature study of the available material gathered on the topic. A selection of relevant documents was followed by the interpretation of applicable data. A critical analysis thereof was done via a process of theological reflection, which led to the key findings and conclusion.

3 In recent times the terms practical theology and pastoral theology have sometimes been used in interchangeable ways (Stephen Pattison and James Woodward, 2000:2-3). However, I would like to make a clear distinction here. In my understanding practical theology is more concerned with integrating wider issues concerning multiple church ministries, homiletics, religious education, social ethics, liturgics, congregational studies etc. All these aspects can be included under the umbrella of practical theology. But pastoral theology is - in the words of Bonnie J. Miller-Mclemore (2014:6) essentially "person- and pathos-centered and focused on the activity of care", ensuring the individual and corporate wellbeing and flourishing of the body of Christ. For a more detailed analysis of the relationship between practical theology, and pastoral theology as part thereof, see e.g. Don Browning (1983); Gerben Heitink (1999) and Daniël Louw (2015).

4 With regard to the pastoral care and counselling movement, American pastoral theologian Robert Dykstra (2005:108) asserts that the undertaking of pastoral theology (in the $21^{\text {st }}$ century) is "experiencing a renaissance, and promising new directions are being chartered." But he also contends, "Some critics have claimed that it is virtually bankrupt, that the movement has overemphasized the secular psychotherapies and psychological sciences and has neglected the theological sciences." Since 1920 pastoral theology has developed interdisciplinary, especially in relation to sociology, psychology and anthropology. Much of the pastoral theology published during the latter half of the twentieth century was organized around a psychological interpretation of human experience. Because of this, the focus on God, as the primary subject matter of pastoral theology, became vague in some ways. See also Andrew Purves (2004:xiv), Holifield (1983), Purves (in McKim and Wright 1992:271) and Buffel (2004). 


\section{Re-affirming the value of contemporary pastoral theology and care from a Reformed perspective}

In this article I argue that pastoral theologians today should take heed not to lose sight of the essential contributions of historical, systematic and biblical theology (McMinn 2007:31). Pastoral theology is indeed as deeply indebted to historical theology and ecclesiastical history as to systematic theology or social ethics (Oden 1983:xi). In the literature studied for the purpose of writing this article, it became clear that much of the literature on contemporary pastoral theology seldom refer to concrete historical examples from a Reformed church background. Therefore it can (ironically) lack in an important dimension needed to foster theological depth and clarity regarding sound pastoral care practices today. ${ }^{5}$

The researcher is convinced that a multi-disciplinary approach to pastoral theology and care is essential. Therefore I value the contributions of sociology, psychology and other social sciences bring to an integrated conversation of what contemporary pastoral care should entail. I would however like to contend that, at least for churches from a Reformed background, as a first step toward meaningfully understanding what pastoral theology and care is supposed to entail today, we need to reconsider the history of its theological development and practice. Furthermore, the ethos and pathos of the Reformers need to be rediscovered. Consequently, in this article some significant reformers' relevance and contribution, both as theologians and pastors, will be in focus.

According to Purves (2004:xxiii), in the Reformed tradition "all theology is rightly practical, and pastoral care is not to be regarded as some kind of 'third thing' alongside Word and sacraments, or even worse, as an applied theology." 6 The study of pastoral theology and care from a Reformed perspective, is obviously influenced by countless inter-denominational theological streams of thought, as well as by several different socio-political and philosophical worldviews, existential and context-specific realities and

5 There are of course some welcome exceptions to this general trend. See for example Gerkin (1997:23-51) and Willimon (2016:27-54).

6 Lindberg (2002:380) affirms this focus of Reformed theologians by stating, "Theology for them was not an abstract academic enterprise, but rather was always related to ministry through Word, Sacrament and service. Theology for them was indeed always 'practical'". 
challenges. ${ }^{7}$ Nevertheless, at its core pastoral theology primarily tries to connect the grace and salvation of God in meaningful and relevant ways with the existential realities humans face daily - including anxiety, grief, despair, hopelessness etc. - via church-related pastoral care practices.

The relationship between pastoral theology and systematic theology is to a great extent complementary. ${ }^{8}$ It actually shares much of the same content, but is distinguished for the sake of convenience and task. Pastoral theology tries to bring exegetical and historical materials to bear on the theory and practice of ministry. It seeks to serve other theological disciplines, for example homiletics, liturgics, pastoral counselling or Christian education, by "unifying them with a single theory of pastoral ministry that leads to an improved integral practice of ministry." (Oden 1983:xi)

Therefore, pastoral theology can without doubt be viewed as an aspect of all theology. In other words, pastoral care itself can contribute a very significant integrating viewpoint on diverse dimensions of church life. According to Scottish pastoral theologian, David Lyall (2001:xviii) pastoral care is "not only the lens through which one can view the worship and mission of the Church, but it is one which can bring into focus both the riches of the Christian tradition and the realities of the lived experience of the Church."

\section{Historical definitions and traditions of pastoral care}

The concept of pastoral care originates from the biblical image of the shepherd (Ps 23, 40:11; Ezek 34:1; Zech 9:16; Jn 10:1-16; Rev 7:17 etc.) .

7 My own view of pastoral theology and care, as subfield of the discipline practical theology, is of course also influenced and shaped by the insights and wisdom of a variety of contexts, church denominations and ecumenical theological traditions, the dominant factor therein being the Dutch Reformed Church and its theological sphere into which I was born and bred, as well as my current involvement with the Reformed Church of Japan, since 2009.

8 The essential content of pastoral theological reflection differs from systematic theology specifically because it includes reflection on concrete situations, case studies or churchly practices. Pastoral theology includes normative, dogmatic reflection. But it also includes interdisciplinary reflection, e.g. by comparing theological, sociological, philosophical and psychological perspectives.

9 It is important to note that the Biblical image of the shepherd is not the only metaphor by which pastoral care can be defined. Contemporary pastoral theologians, like Robert 
God is indeed our true Chief Shepherd in Jesus Christ (1 Pet 2:25, 5:4). Historically within the Christian community, pastoral care embodies the 'cure-of-souls' tradition (cura animarum). Generally, it refers to ordained Christian leaders who bring the resources, love and wisdom of the faith community to meet people's needs. But, it can also be offered by any representative of the church who embodies its values and is committed to God, also in capacities other than traditional church leadership offices.

However, not all helping acts of mercy, love, and charity can be called pastoral care. Clebsch and Jaekle (1964) suggest that the content of care includes the four main pastoral functions, i.e. healing, sustaining, guiding, and reconciling. ${ }^{10}$ They specify a precise content to the care, within a faith community. Thus, pastoral care is aimed at "troubled persons whose troubles arise in the context of ultimate meanings and concerns." (Clebsch and Jaekle 1964:4)

\subsection{A few traits of pastoral care during the pre-Constantinian era}

The content of pastoral care in the early church was mainly shaped by two assumptions. Firstly, pastoral care was strongly focused on the needs of the whole community, rather than simply those of the individual, separate from the community. Secondly, pastoral caregivers assumed that human beings were made in the image of God (Migliore 2004:162). Therefore, only as they lived out the image of God could they be whole and healthy people who foster faith, hope and love.

The apostle Paul reflects very deep pastoral concern in his letters in the Bible. ${ }^{11} \mathrm{He}$ instructs and rebukes, but his writings are filled with love and

Dykstra (2005), propose a wide range of possible images to describe pastoral care. He explicates various classical (e.g. the courageous shepherd), paradoxical (e.g. the wounded healer), as well as current and contextual (e.g. the agent of hope) images of care which are defined by a variety of other contemporary pastoral theologians.

10 Before Clebsch and Jaekle identified these four functions, American Presbyterian minister and pastoral theologian Seward Hiltner published the Preface to Pastoral Theology (1958). Hiltner created a basic theory of ministry and of pastoral care, which was very influential in the pastoral care movement in the USA. He argued that the task of pastoral theology was a disciplined inquiry into the healing, sustaining, and guiding activities of the minister and the church.

11 Smith (1992:89) asserts, "The spirit of all that Paul writes, and all that Luke records of his acts, is supremely pastoral." 
compassion. Paul expected his fellow brothers and sisters to share in every aspect of pastoral care, to build up and encourage each other (for example in 1 Thess 5:11-18; 1 Cor 12:25-26; Rom 12:15; Col 3:16). Paul guided the churches in disputes and answers questions about marriage (1 Cor 7:1-15). He worked tirelessly to reconcile sinners and strengthen the weak. And eventually he sought to let love prevail (1 Cor 13). He reminded believers of his own frailty while requesting their prayers (2 Cor 12:9-10). He also encouraged them to optimize their gifts for the welfare of the broader community (1 Cor 12).

Furthermore, Paul explains a sound Christian doctrine and lifestyle (Tit 2-3). His letters reflect his quest for mutual edification and care, for example Galatians 6:2, "Carry each other's burdens, and in this way you will fulfil the law of Christ." His pastoral manner was filled with affection and transparency. Paul's idea of pastoral care was not aimed at an exclusive group within the church. Indeed, all were deeply involved in the work of ministry. (Ephes. 4:12-16) His ultimate concern was to see men and women brought into a new relationship with God through the gospel. Paul did this in many persuasive, but non-forceful ways. (Beasley-Murray 1993:658)

After the time of Paul, by the close of the first century, the emphasis in care within the church began to change. The great literary work, Shepherd of Hermas, reflected this shift. Its main concern was sin committed after baptism. Pastors were to facilitate both repentance and the sacrament of penance in order to handle this. After this time (around 100-300 A.D.), it was regarded illegal to be a Christian. Christians were identified as 'atheists' who were impairing the state. According to Mills (2005:837), the shift to reconciliation became a dominant theme of pastoral care during this time of persecution.

Subsequently, another major pastoral concern was the encouragement of those who were to be martyred. Bishop Ignatius of Antioch for example, sent letters to the Christian communities on the way to his own martyrdom in Rome. Furthermore, the preservation of the faith tradition was another focus area of pastoral care in the pre-Constantinian era. Baptism was for instance preceded by a three-year instruction period (catechesis).

In short, contends Bondi (2005:327), a large part of pastoral care during the pre-Constantinian era were aimed at three interrelated areas, namely: 
(a) preservation of a tradition handed faithfully from one generation of Christians to the next, (b) preservation of the purity of the church and its faithful members, and (c) support and help for those who needed to lay down their lives for the sake of their witness to the Christian truth.

\subsection{Some characteristics of pastoral care during the post- Constantinian era}

During 313, Constantine proclaimed Christianity as the favoured religion of the empire. Therefore, Christianity became intertwined with the life of the state. With this, the focus of the church's pastoral initiatives shifted again. Martyrdom ended, but pastors were confronted with a new dilemma. That is, how to keep Christianity from simply combining with and absorbing the non-Christian culture around it.

The growth of monasticism tendered some form of a solution. Early on in the monastic tradition, the focus was on formation of Christian character. Furthermore, the early 'Church Fathers' as teachers, bishops etc. had an enormous impact on the nature and integrity of pastoral care. ${ }^{12}$ According to Clebsch and Jaekle (1964:19), many of them acted as "semi-official educators, as dispensers of state welfare funds, as leaders of an imperially endorsed religion, [and as interpreters] of the troubles that beset people."

Care continued to be exercised in various other ways in the church during this period. For example, Augustine (in McNeill 1951:100) suggested a list of pastoral duties:

Disturbers are to be rebuked, the low-spirited to be encouraged, the infirm to be supported, objectors confuted, the treacherous guarded against, the unskilled taught, the lazy aroused, the contentious restrained, the haughty repressed, litigants pacified, the poor

12 Three of these leaders in the fourth and fifth centuries were called Cappadocian Fathers, i.e. Basil of Caesarea; his brother Gregory of Nyssa; and Basil's friend Gregory of Nazianzus. They are also known as defenders of the Nicene orthodoxy. Gregory of Nazianzus (329-390 A.D.) influential writings formed the foundation for the pastoral theology of Pope Gregory the Great (230 years later). Last mentioned Book of pastoral rule remained the primary pastoral care text in the church through the medieval period and the Protestant Reformation, until Martin Bucer's Concerning the true care of souls was written in 1538. (Purves 2001:9-10) 
relieved, the oppressed liberated, the good approved, the evil borne with, and all are to be loved.

In his Treatise on the Priesthood, John Chrysostom described the mark of the true pastor as his willingness to die for his flock (i.e. his congregants). ${ }^{13}$ Chrysostom's most significant pastoral contribution was probably his search for an alternative to the humiliating act of public penance. Subsequently, it becomes clear that early pastoral theological reflection was strongly rooted in daily practices. Theological concepts grew not only from the Bible, but also from everyday experience. ${ }^{14}$ The aim of these concepts and doctrines was to clarify and guide human experience and practice. Many of the leaders who built up the foundations of Christian theology, such as the apostle Paul, St. Augustine and Pope Gregory the Great, who created their theologies directly in the light of their experience of practical, pastoral situations.

By 1200 the church had basically standardized pastoral care practices. The parish priest, as the most educated person in the community, was regarded as counsellor, lawyer, teacher, doctor, and friend. For adults the two great sacraments of healing were the mass and penance. The penance involved contrition, confession and satisfaction. It offered the priest the opportunity to conduct a thorough spiritual examination.

One very prominent feature in this era was the start of educated or 'scientific' approaches to soul care. The Fourth Lateran Council (1215) even described soul care as 'the art of arts'. This suggested that soul care was the most important of all the liberal arts and sciences which were being studied at schools and universities emerging throughout Europe. This elicited the modern expectation that all pastors should ideally receive formal academic training for exercising the functions of soul care. (Goering 2005:700)

13 In the West, Ambrose (bishop of Milan) was Chrysostom's counterpart. His great work, On the Duties of the Clergy was published around 386 A.D. He challenged some of the false principles of heathenism, and indicated the superiority of Christian morality. Furthermore church care and counseling were given to support individuals regarding taxation, marital problems, land disputes and other issues with the government. In other words, pastoral care also dealt with public concerns from early on.

14 "Theology was not what we would now call an academic activity whereby full-time individual thinkers and writers could practice their craft in an educational setting more or less independently of the religious community, its liturgical activity, and its practical concerns." (Pattison and Woodward 2000:23) 
The primary meaning of the Latin word cura is 'care', although it also includes the notion of 'healing' or 'cure'. Understanding the concept soul, in terms of how the Bible describes it, requires exegetical in-depth understanding. Basically, the Hebrew word nephesh and the Greek word psyche are regularly translated with the English word soul. But most Biblical scholars agree that the most accurate meaning of these words are person, or self. David G. Benner aptly asserts that the advantage of such an understanding is that both words (person and self), transmits the idea of wholeness. He contends, "Self is not a part of the person but their totality. Similarly, personhood is not some part of us; it points to the totality of our being." (Benner 1998:22).

Louw (2015b:195) affirms this view by stating,

The whole is always more than its parts. "Soul" is therefore more than reason and the "body" more than psuche. Both body and soul are more than spiritus or flesh (sarx). Human beings are an embodied soul and an ensouled body. As a created whole, a human being is designed for the cause of doxa: to reflect divine destiny (telos), a humane mode of living (Calvin: la principale fin de la vie humaine).

This understanding of the concept of soul leads us to conclude: we do not have a soul, we are a soul. In other words, we embody our soulfulness. Concurrently, we do not have bodies, we are (our) bodies. We are living, vital whole human beings, in soul and body. Care of souls therefore means the care of persons within their network of relationships, Coram Deo (in God's presence) (cf. Louw 2012:29-39).

\section{Pastoral theology and care during the reformation period}

Since the Reformation various understandings of relatedness to God have fostered a variety of traditions of pastoral care, e.g. Roman Catholic, Anglican, Lutheran, and Reformed. I will focus briefly on the development of pastoral care in the Reformed tradition.

Much of the early understanding of pastoral care in the Reformed tradition can be summarized under the practice of discipline. This includes the spiritual discipline of the pastor and the discipline of the congregants. The 
Reformed tradition viewed the issue of sin with earnest. This influenced the emphasis on discipline in pastoral care. Sinfulness was also viewed as the core of the human dilemma, thereby making reconciliation with God essential. (Waanders 2005:1050)

Related to each of these themes was the emphasis on correct teaching and preaching of the Word. Hearing clearly the Word of God convinced persons of their sinful condition, thereby leading them to repentance and reconciliation with God. Following in this regard, the Word was seen as a guide to faith and nourishment for the soul. Furthermore, the relationship of the Word to the sacrament as, well as to the work of the Holy Spirit, was important within Reformed pastoral care. ${ }^{15}$

The need for formal confession was abandoned and the pastor emerged as a central figure. But, the pastor's ordination did not elevate him to a different level. Pastors identified intentionally with their people. Pastors and laypersons alike were mutually to comfort, correct, and sustain each other. Therefore Mills (2005:839) concludes: "The mark of a transformed life lay in mutual ministry with the end of being reconciled to God and to each other."

In my view 2 Corinthians 5:17-21 summarizes the essence of pastoral care during the Reformation era. Pastors indeed viewed themselves as ones that have been given the ministry of reconciliation (v.18). Their core aim was to act as Christ's ambassadors, as though God were making his appeal through them. Therefore they implored their fellow believers on Christ's behalf: "Be reconciled to God" (v. 20).

15 "For first, the Lord teaches and instructs us by His Word. Secondly, he confirms it by the sacraments. Finally, he illuminates our minds by the light of his Holy Spirit and opens our hearts for the Word and sacrament to enter in, which would otherwise only strike our ears and appear before our eyes, but not at all affect us within." (John Calvin, Institutes of the Christian Religion IV.xiv.8) More contemporary Reformed Pastoral theologians also emphasize the essential relation between the Holy Spirit and the human person in pastoral theology. See Rebel (1981) who attempts to bridge the gap between the so-called kerygmatic and psycho-therapeutic soul care in his book titled Pastoraat in pneumatologisch perspektief. His approach is closely associated with the eschatological approach of Van Ruler. See also Louw (168-194) for his significant contribution on the role of pneumatology in the design of a pastoral anthropology. 


\subsection{Characteristics of some Reformers' pastoral care}

\subsubsection{The Early Reformers ${ }^{16}$}

\subsubsection{Martin Luther}

Luther's pastoral practice was characterized by warmth, conviction, and identification with distressed believers. ${ }^{17}$ This was reflected e.g. in his letters of consolation, his concern for the young women who had left the nunneries, his correspondence with friends etc. Luther objected to the authority to bind and loosen sin being restricted to priests. (McNeill 1951:167) All Christians, he said, have authority to hear confessions and absolve. We share a common priesthood just as we share our spiritual gifts. Luther strongly affirmed the simple Gospel truth: who believes in Christ, has the forgiveness of sins.

\subsubsection{Martin Bucer}

Martin Bucer was a German Reformer located in Strasbourg. He influenced Lutheran, Calvinist, and Anglican doctrines and practices. Bucer wrote a very influential book in 1538 titled, Concerning the True Care of Souls. In it he describes a fivefold ministry of soul care. In public and by visitation pastors (1) draw alienated people to Christ, (2) lead back those strayed away, (3) heal those who are injured, (4) strengthen the weak and ailing, and (5) guard those who are healthy and strengthen them properly. (Bucer, translated by Beale 2009:212) Bucer's proposed focus of soul care is strongly influenced by his definition of "the discipline of Christ", i.e.:

"That all the members of Christ recognize and embrace each other most intimately and lovingly, and that they build one another up in the knowledge of and obedience to the Son of God most zealously and efficaciously, and that the ministers of the churches know, care

16 Two more early Reformers include Ulrich Zwingli and Henry Bullinger. For more on Zwingli's contribution, see Waanders (2005:1050). Bullinger role as Zwingli's capable successor, is depicted by McNeill (1951:196).

17 "Pastoral care of the people became a process of facilitating the individual's personal relationship with God. Reconciliation of the individual soul to God and guidance in the spiritual life of members of the community of faith became the central pastoral tasks. Luther's pastoral care likewise concerned itself with the care and protection of those who were victims of the uncaring practices of their society." (Gerkin 1997:42) 
for and tend the individual sheep of Christ, as the chief pastor Christ set the example." (as quoted by Wright in Bucer 2009:xvii)

This unique (in his context and time) definition of church discipline deserves further attention and in-depth research, however such an endeavour exceeds the limits of this article.

\subsubsection{John Calvin and his (other) colleagues}

"The historical portrait of Calvin that has too often emerged is of a dispassionate "theologian", or a rarefied "mind", disengaged from the practical responsibilities and concerns of everyday parish life." (Manetsch 2013:7) But this is not the full story about Calvin. His immaculate level of commitment to his calling and work as pastor in Geneva has recently been depicted afresh by some Calvin specialists, like Scott Manetsche. ${ }^{18}$ This includes his preaching, writing and teaching, as well as his empathetic concern and concrete caregiving for congregants and societal elite, but also for refugees, poor people and many others. Many scholars have recently highlighted that Calvin was a theologian in order to be a pastor above all. A pastor who focused on the "cure of souls". ${ }^{19}$

Calvin's practical concern for church ministry was rooted in a deep selfunderstanding as a pastor, which in many ways let the stern discipline he enforced be outweighed by gentle and genuine compassion, guiding parishioners toward a deeper awareness of God and love for one another. Calvin's care and sympathy for human suffering truly disperses many

18 Manetsch (2013) gives a detailed evaluation of the pastoral behaviour of Calvin and his colleagues, in light of their unique historical and religious contexts. He examines the pastoral theology and practical ministry of Calvin, Beza and various others, as they served as pastors in Geneva's churches between 1536-1609. The way they defined the office and functions of the Reformed pastorate becomes clear. Manetsch (2013:255-298) also gives a sober and striking account of the everyday practice of church ministries. This includes Calvin and his colleagues' preaching, catechesis, pastoral care, church discipline, administration of the sacraments, visitation etc.

19 See John H. Leith (in McKim ed. 1992:15). Furthermore, for a detailed version of the historical development of pastoral care - also known throughout history as the 'cure of souls' - see the seminal work of John T. McNeill (1951). Jean-Daniel Benoit (n.d.:14) claims that The Institutes is not merely a book written by a theologian, but by a person who, before becoming a minister, was captivated by the care of souls. Benoit (n.d.:85) furthermore depicts Calvin as a theologian and psychologist whose understanding of human nature was based on the Bible and on his own experience. 
common misconceptions about him. ${ }^{20}$ His vibrant and heartfelt pietistic spirituality was Christ-centred, and it cultivated his commitment as professor, preacher and pastor. ${ }^{21}$ Calvin laid emphasis on the disobedience of an idolatrous heart as the core of human distress. ${ }^{22}$ What he and his colleagues in Geneva sought to insure was exemplary conduct. The stern discipline which Calvin enforced was outweighed by a gentler Calvin as pastor. His letters expressed his empathy and care for troubled congregants. He wrote to bereaved persons with sincere warmth, but his advice was not sentimental. ${ }^{23}$ He leaned heavily upon Scripture and gave spiritual direction with comforting certitude.

Indeed, pastoral work in the sixteenth and early seventeenth century Geneva was very challenging. It is important to note afresh that, for Calvin and his colleagues, the ministry of the Word required much more than the public exposition of Scripture. Calvin note in one of his liturgies (as quoted by Manetsch 2013:256), "the office of a true and faithful minister is not only to teach the people in public, which he is appointed to do as pastor, but also, as much as he is able, to admonish, exhort, warn, and console each person individually."

Thus, in general Christian pastors were expected to be intensively involved in the congregants' lives. They were supposed to provide nurture to the congregants' Christian understanding and their spiritual lives, from birth to death. John Calvin's final urging to his colleagues (on April 28, 1564)

20 For more detailed descriptions of Calvin's thought and practice as pastoral theologian, see e.g. Reid (1982), Ryan (2000).

21 Joel R. Beeke (in McKim ed. 2004:125) stresses the importance of not separating Calvin's acclaimed intellectual genius from the "vital spiritual and pastoral context in which he wrote his theology." Beeke indicates convincingly that Calvin's pietas, firmly rooted in his mystical union with Christ and his fervent prayer life, deeply influences the ecclesiological, practical and theological aspects of his logic and understanding.

22 Man's nature, so to speak, is a perpetual factory of idols ... Man's mind, full as it is of pride and boldness, dares to imagine a god according to its own capacity; as it sluggishly plods, indeed is overwhelmed with the crassest ignorance, it conceives an unreality and an empty appearance as God. (John Calvin, Institutes of the Christian Religion I.xi.8)

23 "Calvin also wrote to kings and queens and other prominent persons encouraging them to be faithful Christians and urging their protection and advocacy of the church. His letters reflect deep care for persons who were ill or bereaved and patience with political complexities. He wrote to prisoners soon to die during the persecutions of Henry II of France." Calvin not only sought political means to secure their release, but he also inquired after their souls. (Waanders 2005:1051) 
a month before his death in was to "change nothing" (2013:1). Theodore Beza and his pastoral colleagues took this to heart, and in many ways conservatively tried to resist various efforts to modify church doctrine and practice. But, as Manetsch indicates convincingly, religious life and pastoral practice did change in significant ways (specifically between 1536 and 1609).

Geneva's pastors such as Beza, Daneau, Chandieu, and Goulart applied the main tenets of Reformed theology to the ethical issues and spiritual needs of new generations of Reformed Christians in Europe. In this way they offered their brothers and sisters biblical wisdom, spiritual consolation and practical instruction. Although they developed certain aspects of Calvin's theology, "these changes were not a betrayal of Calvin's theological program per se but reflected their commitment to interpret Scripture and apply Calvin's thought in light of new questions and new contexts." (2013:302)

Obviously, after the Reformation era there has been major and significant developments in the theory and practice of pastoral theology and care, in a plethora of global contexts. An in-depth analysis thereof however exceeds the limits of this article. Therefore, in this final part I conclude by gleaning insights from the historical perspectives mentioned hitherto.

\section{Key findings about pastoral care from the history of the church}

What can we learn from the Reformation period, as well as from before that time, which meaningfully links to our context today? Can we, in a similar way as Calvin's colleagues, meaningfully incorporate his and other Reformers' pastoral theological thought and ethos more intentionally, in light of new questions in our contemporary contexts? How can we foster Christian hope and comfort that can sustain people in precarious times filled with uncertainty? These are the type of pastoral theological questions at stake that I think we need to grapple with.

Basically we, like the Reformers, need to keep on reforming. We are, like them, called to stay faithful to Biblical norms while getting all the more practically involved with our unique, local context - in my case currently Japan, and periodically South Africa. We need wisdom concerning the 
complexity of our human condition. In this reality we are called to embody the grace of our Lord Jesus Christ, the love of God our Father, and the comforting fellowship of the Holy Spirit (2Cor. 13:13). This remains the essential calling of pastoral theology and pastoral care.

Manetsche (2013:304-306) garnered the following insights for today, from pastoral life as it was practiced and understood in the time of Calvin's sixteenth century Geneva:

- Calvin and his so-called company of pastors placed a very high priority on the actual ministry of pastoral care. ${ }^{24}$ Today, some aspects of Calvin's program of pastoral supervision and discipline might seem unduly intrusive. But when we see it within its historical context, and when we remember that it was aimed at the spiritual well-being and growth of all, we get a new perspective. ${ }^{25}$

- The Bible as authoritative Word of God undoubtedly played a central role in church Reformation. Spiritual reformation and scriptural proclamation went hand in hand.

- Calvin and his colleagues highly valued accountability and collegiality in pastoral work. As equal partners in ministry they supervised one another's pastoral work, under the authority of Christ. They were mutually dependent upon and subject to each other. ${ }^{26}$

- The vocation of Christian ministry was complex. Pastors faced heavy workloads and many pressures. They encountered many hardships, including financial deprivation, incessant public criticism, congregational apathy, and sometimes even physical danger.

24 The message of the Bible had to be put into practice in their congregants' everyday lives. This was strengthened by the baptism of infants, teaching of catechism to children, welcoming of young adults at Eucharist, visiting households, comforting the ill and consoling those who faced death. (Manetsche 2013:306)

25 "Indeed, in our modern world where men and women so often struggle with spiritual dislocation, fractured relationships, and deep-seated loneliness, Calvin's vision for pastoral oversight that includes gospel proclamation and intense relational ministry appears especially relevant and important." (Manetsche 2013:306)

26 "Contemporary Protestantism, with its infatuation for robust individualism, celebrity preachers, and ministry empires, has much to learn from the example of Geneva's church." (Manetsche 2013:305) 
Evidently, the complexity of Christian ministry during the Reformation was a significant characteristic. Pastors faced multiple pressures and strenuous workloads. They learnt that their context had to shape their pastoral response. Pastoral practice was not just about applying some spiritual formula. Pastors needed to develop wisdom in order to discern what interventions to implement in each particular case. And they made mistakes in the process. But they kept their focus on the care of souls, as it was understood within their context.

We learn furthermore that pastoral work is not hurried, but pastors need to take time to prayerfully reflect on the ministry they have been given. Pastors need to immerse themselves in their congregants' lives, in order to stand in awe of what God is doing with those people ${ }^{27}$. Pastors that give most of their time for administrative work or various para-church involvements (albeit relevant), cannot do this. Priority needs to be given to really knowing and understanding people through practical care giving (i.e. soul care). Sound Reformed doctrine and even good preaching cannot substitute compassionate Christian love for others. But it can and should augment it. This is one premise of pastoral care that needs to be revisited regularly, whether by Reformed churches in Japan, South Africa or elsewhere.

Lastly, it is important to realize that pastoral ministry in the Reformation era entailed much more than preaching skills and administrative or disciplinary tasks. It included deep knowledge of God, nurtured by personal encounters with God. Furthermore, pastoral ministries' effectiveness also depended upon deep knowledge about others and themselves as caregivers. This core insight is presented very eloquently by John Calvin in the introduction to his Institutes of the Christian Religion. ${ }^{28}$

27 Eugene Peterson (1989:4) writes in his book The contemplative pastor, “The pastor's question is, 'Who are these particular people, and how can I be with them in such a way that they can become what God is making them?'”

28 In the first chapter of the Institutes, Calvin asserts that without knowledge of self, there is no knowledge of God. Likewise, he contends that without knowledge of God there is no knowledge of self. This mutuality between knowing God and knowing ourselves occurs in the experience of facing God's majesty. According to Calvin, faith is contemplating the face of God - faciem Dei contemplari. (cf. Institutes of the Christian Religion 1.1.1,2). Thus, in the light of these assumptions it can be argued that: a meaningful understanding of human beings is impossible without an understanding of 
Indeed, from the perspective of the Reformation, personal identity (including pastoral identity) is first and foremost defined by Christian identity. ${ }^{29}$ Through encountering God we simultaneously encounter ourselves. Pastoral Theology is therefore also about understanding who we are as humans, in light of who God is. Consequently, Christian caregivers today, especially pastors, need a thorough self-knowledge, in order to guide, care for and equip others with authenticity ${ }^{30}$.

In line with this, theological training should indeed revolve around much more than rote learning of academic theological ideas. The seedbed for fruitful pastoral care ministries starts in seminaries and training centres, with the focus on fostering spiritually and emotionally mature pastoral caregivers. Pastors who are fully aware of their own woundedness, can indeed become wounded healers and agents of hope, who embody God's

God. In other words: knowledge of ourselves and knowledge of God are given together. To know God is to be changed by God and to experience the power of God. According to Benner (1998:100) "Discovery of our true self, our self-in-Christ, is made possible by God knowing us. He then reveals our true self to us." Furthermore, the inquiry, 'Who am I?' is interconnected with the question, 'Who are we?' (Theron 2006:114). Personal identity has a composite character, which comprises many identities, including for instance being a women or a man, a Japanese or a South African.

29 McGrath (1994:42-55) identifies four basic themes as underlying the spirituality of the Reformation. Firstly, it is grounded and nourished in the study of Scripture. The sola scriptura principle, so central to the theological method of the Reformers, is equally evident in their spirituality. Secondly, it explicitly recognizes the priesthood and vocation of all Christian believers. In the third place, Reformation spirituality insists that the quest for human identity, authenticity, and fulfillment cannot be undertaken in isolation from God. To find out who we are, and why we are here, is to find out who God is and what he is like. Lastly, Reformation spirituality is grounded in and oriented toward life in the everyday world, enabling Christians to involve themselves firmly and fully in the life of the secular order, while at the same time lending it new meaning and depth.

30 Benner (1998:99) highlights the unfortunate consequence when people do not realize the deep connection between spiritual and psychological wholeness, including proper knowledge of oneself and of God. "The result has been outward postures of piety that are dramatically incongruent with the actual state of the inner world. This lack of authenticity is usually apparent to everyone other than the individual, who defends against such an awareness by an increasing reliance on denial and projection. This, in turn, leads to rigidity and an ever widening gap between inner reality and outer appearances." Pastors are not exempt to this danger. 
comfort. ${ }^{31}$ Thus, a clear pastoral identity is necessary, in order not to 'burnout' in ministry, but to flourish. ${ }^{32}$

\section{Conclusion}

Constructive research about historical pastoral theological perspectives can help us to create well-balanced pastoral theological approaches and care practices today. A re-reading of the classical pastoral care writings specifically including those of prominent Reformers - can direct us to sound, critical thought concerning the purpose of pastoral work in contemporary times, in an array of church and community contexts, within the Reformed tradition and beyond.

Leading Reformers like John Calvin and his colleagues had particular gifts to fulfil their calling as pastors, by interpreting the relationship between the Word of God's content and the lives of God's people. Through their writings and in many other practical ways, they connected God's grace and salvation meaningfully with the existential realities their fellow humans faced daily.

Through this short overview of the historical development of pastoral theology and pastoral care, it became clear that cura animarum remains the essential function of pastoral caregivers today. In Church history this assumption has always been pivotal to understanding the task and meaning of the pastoral ministry. This core focus needs to be theologically re-defined in secularized societies.

31 Embodiment is an important theme in pastoral care. According to Campbell (1986:16), "Pastoral care as integrity must therefore be, first and foremost, the presence of one person with another which precedes all words. Pastoral care is embodied care, care incarnate."

32 Pastoral ministry disconnected from Biblically sound pastoral theology can become exclusively skill-driven. This is a recipe for burnout, contends Oden (1983:5): "Doubtless a major cause of "burnout" in ministry is the blurring of pastoral identity, or the confusion concerning what ministry is. The neglected remedy is solid re-rooting in classical pastoral wisdom, which has carefully held together Christ's ministry and ours, God's gift and the church's task, grace and responsiveness. Many complications of burnout in ministry could have been prudently avoided by building a better biblical foundation, one that rings with the wisdom of twenty centuries of experience in ministry." 
Pastors and caregivers in Reformed churches worldwide need to learn about Pastoral Theology and Care in ways that are Biblically sound, culturally alert and sensitive to the existential needs of people. Theological institutions worldwide, which offer training from a Reformed perspective will do well to ensure that theologically balanced, socio-psychologically informed, and contextually relevant Pastoral Theology and Care training is offered, which also take into account the historical perspectives that was presented in this article.

The theological education of pastors in churches with a Reformed heritage, does not necessarily need to strive to imitate Reformers like Calvin, Luther or Bucer's actual pastoral practices. But, in my view, Reformed theological educators and pastors alike will benefit from a fresh re-appreciation of these initial Reformers' pastoral theological ethos and pathos. By doing this, we take part in the ongoing history of the Reformation - always reforming by critically retrieving our heritage, for it shapes our future identity from the roots up.

\section{Bibliography}

Beasley-Murray, P 1993. Paul as pastor. In: GF Hawthorne \& RP Martin (eds.). Dictionary of Paul and his letters. Leicester: InterVarsity Press. 654-658.

Beeke, JR 2004. Calvin on Piety. In: DC McKim (ed.). The Cambridge Companion to John Calvin. Cambridge: Cambridge University Press. 125-152.

Benner, DG 1998. Care of Souls: revisioning Christian nurture and counsel. Grand Rapids: Baker Books.

Benoit, J-D n.d. Calvijn als Zielzorger. Translated by AJA Mondt-Lovinck. Nijkerk: Callenbach.

Bondi, RC 2005. Pastoral care and counseling in early church. In: RJ Hunter \& NJ Ramsay (eds.). Dictionary of pastoral care and counseling. Nashville: Abingdon Press. 327-329.

Browning, DS (ed.) 1983. Practical theology: The emerging field in theology, church, and world. Harper \& Row. 
Bucer, M 2009. Concerning the true care of souls (1538). Translated by

Peter Beale. USA: Versa Press, Inc.

Buffel, OA 2004. Deliver us from Individualism and clericalism:

Liberating Pastoral care from Western individualism and clericalism.

Practical Theology in Southern Africa. 19(2):37-51.

Campbell, AC 1986. Rediscovering pastoral care (second edition). London: Darton, Longman and Todd.

Calvin, J \& Battles, FL 2001. Calvin: Institutes of the Christian religion. Louisville: Westminster John Knox Press.

Clebsch, W \& Jaekle, C 1964. Pastoral Care in Historical Perspective: An Essay with Exhibits. Englewood Cliffs: Prentice-Hall.

Dykstra, RC 2005. Images of pastoral care: classic readings. St. Louis, Missouri: Chalice Press.

Gerkin, CV 1997. An introduction to pastoral care. Nashville: Abingdon Press.

Goering, J 2005. Pastoral Care in Medieval Church. In: RJ Hunter \& NJ Ramsay (eds.). Dictionary of pastoral care and counseling. Nashville: Abingdon Press. 698-700

Heitink, G 1999. Practical theology: History, theory, action domains: Manual for practical theology. Grand Rapids, Michigan: Wm. B Eerdmans Publishing.

Holifield, EB 1983. A History of Pastoral Care in America: From Salvation to Self-Realization. Nashville: Abingdon Press.

Johnson, EL 2007. Foundations for soul care: a Christian psychology proposal. Illinois: IVP Academic.

Leith, JH 1992. The Ethos of the Reformed Tradition. In: DK McKim (ed.). Major Themes in the Reformed Tradition. Grand Rapids: Eerdmans. 5-18.

Lindberg, C (ed.) 2002. The Reformation Theologians: an introduction to theology in the early modern period. Oxford: Blackwell Publishers Ltd. 
Louw, DJ 1998. A pastoral hermeneutics of care and encounter: A theological design for a basic theory, anthropology, method and therapy. Cape Town: LuxVerbi. BM.

- 2012. Network of the human soul: on identity, dignity, maturity and life skills. Stellenbosch: SUN Media.

- 2015. Wholeness in hope care: on nurturing the beauty of the human soul in spiritual healing. Zürich: LIT Verlag.

Lyall, D 2001. The integrity of pastoral care. London: SPCK.

Manetsch, SM 2013. Calvin's company of pastors: pastoral care and the emerging Reformed Church, 1536-1609. Oxford: Oxford University Press.

McGrath, AE 1994. Spirituality in an age of change: rediscovering the spirit of the reformers. Grand Rapids: Zondervan Publishing House.

McMinn, MR 2007. Psychology, theology and spirituality in Christian counseling. Wheaton: Tyndale.

McNeill, JT 1951. A history of the cure of souls. New York: Harper \& Bros.

Migliore, DL 2004. Faith seeking understanding: an introduction to Christian theology (second edition). Grand Rapids: Eerdmans.

Miller-McLemore, BJ (ed.) 2014. The contributions of practical theology. In: BJ Miller-McLemore (ed.). The Wiley Blackwell Companion to Practical Theology. 1-20. West Sussex: John Wiley \& Sons, Ltd.

Mills, LO 2005. Pastoral Care (History, Traditions, and Definitions). In: RJ Hunter \& NJ Ramsay (eds.). Dictionary of pastoral care and counseling. Nashville: Abingdon Press. 836-844.

Mikoski, GS 2014. Mainline Protestantism. In BJ Miller-McLemore (ed.). The Wiley Blackwell Companion to Practical Theology. West Sussex: John Wiley \& Sons, Ltd. 557-566.

Oden, TC 1983. Pastoral Theology: Essentials of ministry. New York: HarperCollins.

Peterson, EH 1989. The contemplative pastor: returning to the art of spiritual direction. Grand Rapids: Eerdmans. 
Pattison, S \& Woodward, J 2000. An introduction to pastoral and practical theology. In: J Woodward and S Pattison (eds.). The Blackwell reader in pastoral and practical theology. Oxford, UK:

Blackwell Publishers. 1-22.

Purves, A 1992. Pastoral Theology. In: DK McKim \& DF Wright.

Encyclopedia of the Reformed Faith. Louisville: Westminster / John Knox Press. 271.

- 2004. Reconstructing Pastoral Theology: a Christological foundation. Louisville: Westminster / John Knox Press.

Rebel, JJ 1981. Pastoraat in pneumatologisch perspektief: Een theologische verantwoording vanuit het denken van $A$ A van Ruler. Kampen: Kok.

Reid, WS 1982. John Calvin, Pastoral Theologian. Reformed Theological Review. 41(3):65-73.

Ryan, M 2000. The Pastoral Theology of John Calvin. The Burning Bush. 6(1):32-47.

Waanders, DW 2005. Reformed Pastoral Care. In RJ Hunter \& NJ Ramsay (eds.). Dictionary of pastoral care and counselling. Nashville: Abingdon Press). 1050-1051.

Willimon, WH 2016. Pastor: The theology and practice of ordained ministry (Revised Edition). Nashville, TN: Abingdon Press. 